\title{
Characterization of Two New Electrophoretic Variants of Human Triosephosphate Isomerase: Stability, Kinetic, and Immunological Properties
}

\author{
J. Asakawa ${ }^{1,2}$ and H. W. Mohrenweiser ${ }^{1}$ \\ Received 3 Apr. 1981-Final 17 June 1981
}

\begin{abstract}
Two new electrophoretic variants of human triosephosphate isomerase (TPI) have been partially purified and characterized. The TPI Manchester variant, a cathodally migrating electrophoretic allozyme identified in an individual with the phenotype TPI 1-Manchester, is associated with a normal level of enzyme activity in erythrocytes and normal kinetic properties. It is very thermolabile at 55 and $57^{\circ} \mathrm{C}$, although it is not uniquely sensitive to either guanidine- $\mathrm{HCl}$ or urea denaturation. The TPI Hiroshima-2 variant is an anodally migrating allozyme (the phenotype of proband is TPI 1-Hiroshima-2) with normal activity and kinetic properties and also normal stability characteristics. It is inactivated less by antisera raised against normal human TPI than either the normal or the Manchester allozyme. Dissociation-reassociation experiments utilizing these allozymes have confirmed that normal human red blood cell TPI isozymes are produced by a sequence of reactions (presumably deamidations) involving alternating subunits.
\end{abstract}

KEY WORDS: triosephosphate isomerase; variants; human; structural characteristics.

\section{INTRODUCTION}

Human triose phosphate isomerase (TPI; EC 5.3.1.1), a dimeric enzyme ( $M W=53,000)$ of identical subunits (Yuan et al., 1979), catalyzes the

Financial support was derived from Contract EY-77-C-02-2828 from the Department of Energy.

${ }^{1}$ Department of Human Genetics, University of Michigan Medical School, Ann Arbor, Michigan 48109.

${ }^{2}$ Present address: Radiation Effects Research Foundation, Hiroshima, 730, Japan. 
interconversion of glyceraldehyde-3-phosphate and dihydroxyacetone phosphate and is thus involved in both glycolysis and gluconeogenesis as well as glyceride synthesis. This enzyme is found in a wide variety of tissues in many different species (Scopes, 1968; Gracy, 1974; Snapka et al., 1974) and has been purified and characterized from many sources (Krietsch et al., 1970; Putman et al., 1972; Sawyer et al., Eber and Krietsch, 1980). The primary sequence of TPI has been extensively conserved through evolutionary time; the rate of acceptable amino acid substitutions is estimated at 2.8 mutations per 100 residues per 100 million years (Dayhoff, 1978). Sequence studies of human, rabbit, and chicken TPI indicate a sequence homology of greater than 95\% (Dayhoff, 1978; Yuan et al., 1981) with almost complete homology in the region of the active site (Hartman and Gracy, 1973). The kinetic properties of the enzyme isolated from different species are quite similar (Krietsch et al., 1970). The very high activity of this enzyme suggests that it should not represent a metabolically rate-limiting step. It is, therefore, surprising that severe metabolic consequences involving hemolytic anemia, growth retardation, neurological disorders, and early death are observed when the enzyme activity is reduced to $5-20 \%$ or normal (Schneider et al., 1968).

Some 15 cases of TPI deficiency have been reported (Schneider et al., 1965; Skala et al., 1977; Vives-Corrons et al., 1978). Data obtained by Eber et al. $(1979,1981)$ and Mohrenweiser (1981) indicate that a null alleles(s) associated with a significant reduction in TPI activity occurs in 1 of every 100-200 newborns. It is, as yet, unclear whether a limited number of null alleles exist at relatively high frequencies or whether a large number of different alleles are segregating in this population. The latter situation would suggest that many amino acid substitutions adversely affect enzyme function.

In contrast to null variants, electrophoretic variants of TPI are relatively rare. Peters et al. (1973) described the characteristics of two variants of TPI identified in 3 of 2477 individuals screened. Four variants were identified during the screening of 10,245 Japanese individuals (Neel et al., 1980b), one variant was detected in a population of 1949 individuals studied in Ann Arbor, Michigan (Neel et al., 1980a), and no variants were detected during the study of 3888 Amerindians (Neel, 1978).

The present paper describes the purification and characterizationelectrophoretic as well as stability, immunological, and kinetic properties-of two TPI variants, one identified in Ann Arbor, Michigan (Neel et al., 1980a), designated TPI Manchester (Decker and Mohrenweiser, 1981), the proband having the phenotype TPI-1 Manchester, and the other identified in Japan (Neel et al., 1980b) and designated TPI Hiroshima-2, the phenotype of the proband being TPI 1-Hiroshima-2. 


\section{MATERIALS AND METHODS}

Electrophoresis. Polyacrylamide gel electrophoresis was performed employing a miniaturized vertical gel apparatus (Ogita and Markert, 1979) and the imidazole/ $\mathrm{HCl}(p \mathrm{H} 7.4)$ gel buffer-imidazole/asparagine $(p \mathrm{H} 7.0)$ electrophoresis buffer system of Maurer and Allen (1972). The isoelectric focusing apparatus was from LKB Instruments, Inc., Rockville, Md., and the focusing was carried out on thin-layer polyacrylamide gels. The $p \mathrm{H}$ was determined at $4^{\circ} \mathrm{C}$. The technique of Decker and Mohrenweiser (1981) was used for detecting enzyme activity following electrophoresis.

Enzyme Purification. TPI from erythrocytes of an individual with a normal electrophoretic pattern for TPI was purified as described by Gracy (1975) and Yuan et al. (1979), except for the ommission of the isoelectric focusing step (Table I). The final specific activity was 9070 units $/ \mathrm{mg}$ protein, consistent with specific activities previously reported for purified human TPI (Rozacky et al., 1971; Yuan et al., 1979; Eber and Krietsch, 1980). Also, only a single band was detected on SDS gel electrophoresis, thus the enzyme was assumed to be homogeneous and was used for antibody production.

Individual bands of allozyme(s) were purified from erythrocytes of appropriate individuals (Manchester variant, Hiroshima-2 variant, and normal) by polyacrylamide gel electrophoresis of the enzyme fraction obtained from the first DEAE-cellulose fractionation. The specific activity of the partially purified samples before electrophoresis was $800-1700$ units $/ \mathrm{mg}$. The gel utilized in the purification was $30 \times 8 \times 0.27 \mathrm{~cm}$. A reverse discontinuous concentration gradient of $4 \%(1 \mathrm{~cm}), 7 \%(8 \mathrm{~cm}), 5 \%(21 \mathrm{~cm})$ acrylamide was employed. The buffer system was described above and electrophoresis was carried out for $26 \mathrm{hr}$ at $350 \mathrm{~V}$ and $4^{\circ} \mathrm{C}$. Following electrophoresis, the positions of the isozyme bands were identified as described above. The gel section corresponding to the position of the various

Table I. Isolation of Normal Triosephosphate Isomerase from Human Erythrocytes

\begin{tabular}{lrrrc}
\hline & $\begin{array}{c}\text { Total } \\
\text { activity } \\
\text { (units) }\end{array}$ & $\begin{array}{c}\text { Total } \\
\text { protein } \\
\text { (mg) }\end{array}$ & $\begin{array}{c}\text { Specific } \\
\text { activity } \\
\text { (units/mg) }\end{array}$ & $\begin{array}{c}\text { Recovery } \\
(\%)\end{array}$ \\
\hline Hemolysate & 125,000 & 56,800 & 2.1 & $(100)$ \\
Phosphocellulose filtration & 118,750 & 3,392 & 35 & 95 \\
Ammonium sulfate (55-90\%) & 97,000 & 1,276 & 76 & 77 \\
DEAE-cellulose chromatrography (1) & 82,450 & 242 & 340 & 66 \\
DEAE-cellulose chromatrography (2) & 73,100 & 16.2 & 4500 & 58 \\
Ammonium sulfate (60-90\%) & 54,800 & 8.4 & 6500 & 44 \\
Sephadex G-100 & 49,000 & 5.4 & 9070 & 39 \\
\hline
\end{tabular}


individual bands of activity in each lane was cut into small pieces and the enzyme was extracted into a buffer composed of $50 \mathrm{mM}$ triethanolamine (TEA), $1 \mathrm{~mm}$ EDTA, $100 \mathrm{~mm} \mathrm{NaCl}$, and $0.01 \%$ 2-mercaptoethanol $(p \mathrm{H}$ 7.6). The extracted enzyme was concentrated by dialysis against polyethylene glycol. The concentrated isolated enzyme fractions, with an estimated specific activity of 5000 units per $\mathrm{mg}$, were stored in liquid $\mathrm{N}_{2}$ in the presence of 1 $\mathrm{mg} / \mathrm{ml}$ of bovine serum albumin until used.

Antisera Production. Antisera against human TPI were produced by repeated injection of $0.1 \mathrm{mg}$ of purified normal human TPI in $0.5 \mathrm{ml}$ saline and $0.5 \mathrm{ml}$ Freund's incomplete adjuvant, subcutaneously, into a rooster at 1 , 2 , and 4 weeks after the initial injection. Two days after the fourth injection, $0.05 \mathrm{mg}$ TPI in saline was injected intravenously, and 4 days later blood was collected and allowed to clot and the serum was removed. The rooster serum was heated at $60^{\circ} \mathrm{C}$ for $60 \mathrm{~min}$ and the denatured protein was removed by centrifugation at $48,000 \mathrm{~g}$ for $30 \mathrm{~min}$. No TPI activity was detectable in rooster serum after heating. The antisera appeared to be monospecific, as only a single precipitation band was observed on Ouchterlony double diffusion analysis with either purified or unpurified TPI, including crude hemolysate as the source of antigen.

Immunoinactivation. Immunoinactivation experiments were conducted by incubating 3.75 units of purified TPI in $90 \mu \mathrm{l}$ of extraction buffer containing $1 \mathrm{mg} / \mathrm{ml}$ bovine serum albumin with $10 \mu \mathrm{l}$ of antiserum. After $5 \mathrm{hr}$ of incubation at $36^{\circ} \mathrm{C}$ and centrifugation at $48,000 \mathrm{~g}$ for $30 \mathrm{~min}$, the supernatants were assayed for residual activity.

$p H$ Stability. The stability of the allozymes to incubation at various $p \mathrm{H}$ levels was examined by incubating 2.5 units of TPI in $100 \mu$ of buffer, 100 mM TEA-HCl or TEA-NaOH, $1 \mathrm{~mm}$ EDTA, and 5\% sucrose for $6 \mathrm{hr}$ at $36^{\circ} \mathrm{C}$. After incubation the sample was diluted with $1 \mathrm{ml}$ buffer $(100 \mathrm{mM}$ TEA, $1 \mathrm{~mm}$ EDTA, and $0.01 \%$ 2-mercaptoethanol, $p \mathrm{H} \mathrm{7.6)}$ and assayed for activity.

Guanidine- $\mathrm{HCl}$ Denaturation. Twenty-five microliters of TPI solution was mixed with an equal volume of 1.8 or $2.2 \mathrm{M}$ guanidine- $\mathrm{HCl}$ in $50 \mathrm{mM}$ TEA buffer, $p \mathrm{H} \mathrm{7.6.} \mathrm{After} \mathrm{incubation} \mathrm{at} 30^{\circ} \mathrm{C}$ for $30 \mathrm{~min}$ the solution was diluted with $0.5 \mathrm{ml}$ of dilution buffer $\left(4^{\circ} \mathrm{C}\right)$ and the remaining activity was determined.

Other Methods. Thermostability studies were conducted as described by Satoh and Mohrenweiser (1979) except that when purified isozyme bands were studied, the thermodenaturation incubation buffer contained $1 \mathrm{mg} / \mathrm{ml}$ bovine serum albumin. Urea dissociation/reassociation experiments were conducted following the methodology described by Rubinson et al. (1973). 
Enzyme activity was measured as described by Fielek and Mohrenweiser (1979). The $K_{m}$ values were determined by the unweighted nonlinear regression method of Wilkinson (1961) using the computer program described by Tiffany et al. (1973). Substrate was prepared as described by Gracy (1975) and the concentration of D-glyceraldehyde-3-phosphate was determined enzymatically as described by Bergmeyer (1974).

Materials. Ion-exchange resins were from Whatman Inc., Clifton, N.J. Ammonium sulfate, urea, and guanidine- $\mathrm{HCl}$ were the "ultra pure" grade from Schwarz/Mann, Orangeburg, N.Y., and were used without further purification. Substrates, inhibitors, and cofactors for the enzyme assays were from Calbiochem-Behring Corp., La Jolla, Calif. Bovine serum albumin was from Miles Laboratory, Elkhart, Ind., and was free of detectable TPI activity (Porter et al., 1973). Rabbit muscle TPI was from Boehringer Mannheim Biochemicals, Indianapolis, Inc. All other chemicals were analytical/reagent grade.

\section{RESULTS}

\section{Electrophoresis of TPI Variants}

The polyacrylamide gel electrophoresis patterns for the two variants of TPI as well as a normal pattern are shown in Fig. 1. The electrophoretic pattern of enzyme from an individual with the phenotype TPI 1-Manchester is in well 2. The TPI-Manchester variant allozyme migrates cathodally, relative to the position of the normal allozyme band (wells 1,3 , and 5). The banding pattern is consistent with that expected for a dimeric enzyme with identical subunits. A similar electrophoretic pattern is observed in lymphocytes isolated from this individual (Decker and Mohrenweiser, 1981) except that the degradation bands, presumably resulting from spontaneous deamidation (Gracy and Yuan, 1980), are not as apparent in the electrophoretogram with enzyme from lymphocytes. The electrophoretic mobility is consistent with a charge change of approximately +2 units per subunit for the Manchester variant. The level of TPI activity in erythrocytes from this adult individual was $115,000 \mu \mathrm{mol}$ product formed $/ \mathrm{g} \mathrm{Hb} / \mathrm{hr}$, which is comparable to the value of $124,000 \pm 18,000 \mu \mathrm{mol}$ described by Mohrenweiser (1981), as expected for an adult population. This variant has been identified in a father and two children.

The pattern for the proband with the phenotype TPI 1-Hiroshima-2 is in lane 4. The TPI-Hiroshima-2 variant allozyme has an anodal mobility, the presumptive homodimer having a mobility similar but not identical to that of the second deamidation band of the normal isozyme or the " $c$ " band of Peters et al. (1973), although this distinction cannot be made when starch is utilized 


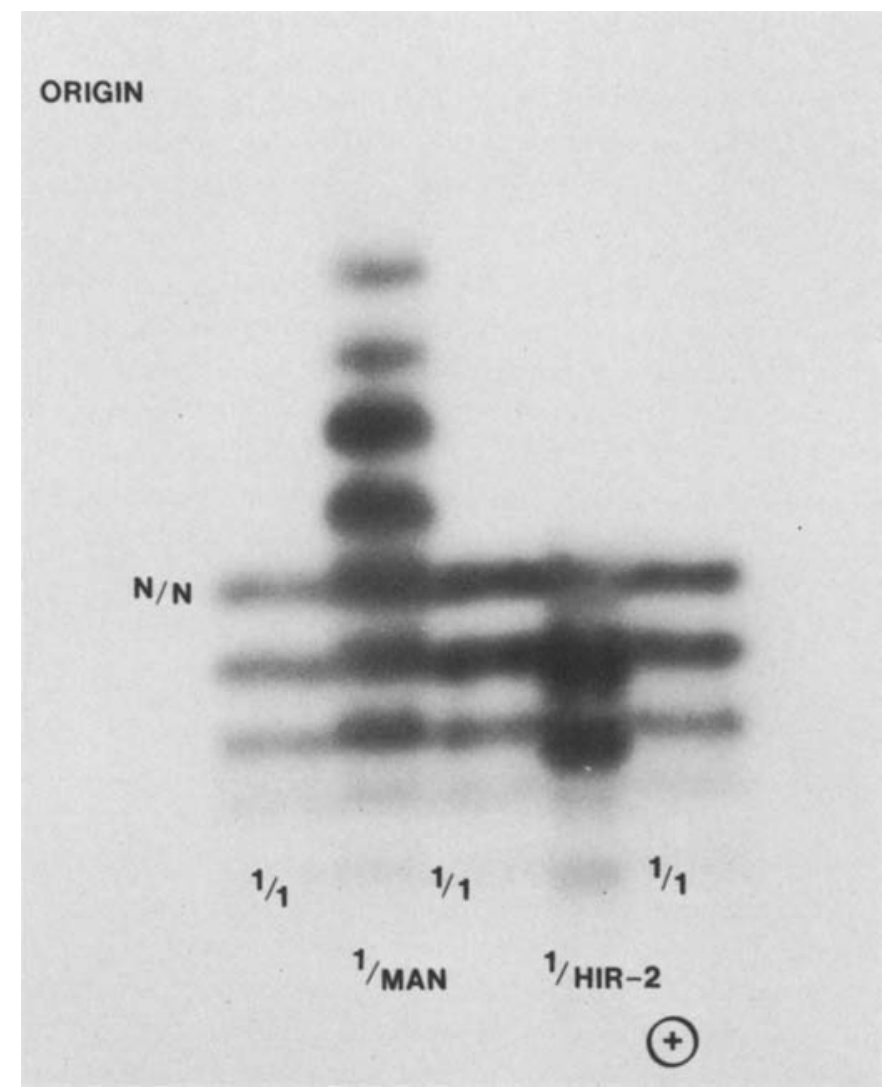

Fig. 1. Polyacrylamide gel electrophoretic pattern of normal and variant TPI. The hemolysates were fractionated on a phosphocellulose columan before electrophoresis. The phenotypes are (1) TPI 1 (normal), (2) TPI 1-Manchester, (3) TPI 1, (4) TPI 1-Hiroshima 2, and (5) TPI 1. The gels were stained for TPI activity as described in Materials and Methods. The position of the primary isozyme band in the normal phenotype is designated N/N.

as the support, rather than polyacrylamide. It would appear, though, that this variant is not identical to the TPI-3 variant described by Peters et al. (1973), although direct comparisons were not made. The mobility of this variant is consistent with a net charge change of approximately -1 unit per subunit. The TPI activity in erythrocytes from this adult individual was 138,000 $\mu \mathrm{mol} / \mathrm{g} \mathrm{Hb} / \mathrm{hr}$, again well within the normal range of activity. The inheritance of this variant has also been confirmed via family studies.

A simplified schematic diagram of the electrophoretic pattern is in Fig. 2. The patterns in lanes 1 and 5 are those postulated for the rare TPI Manchester and TPI Hiroshima-2 homozygotes, respectively. $\mathbf{M}, \mathbf{N}$, and $\mathbf{H}$ 


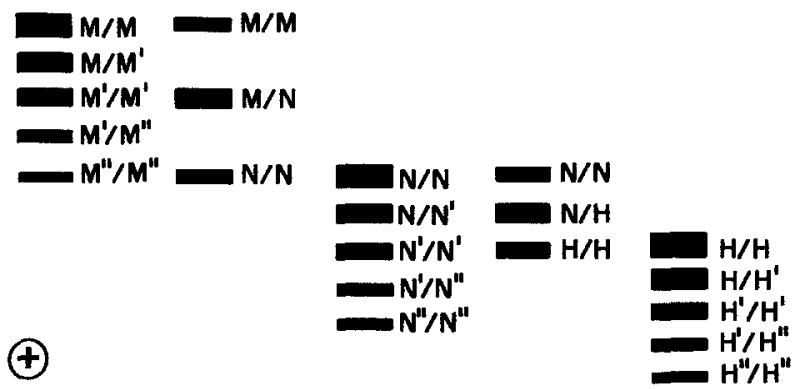

Fig. 2. Schematic diagram of TPI allozyme electrophoretic patterns. Designations are as follows: $M$, Manchester subunit; N, TPI 1 subunit; H, Hiroshima-2 subunit; (') and (") indicate onceand twice-deamidated subunits. Lanes 1 and 5 are the postulated patterns for the rare homozygous TPI Manchester and Hiroshima2 individuals, respectively. Only the primary allozymes are indicated for the two heterozygous probands.

refer to the Manchester, normal, and Hiroshima-2 subunits, respectively, while $\mathrm{M}^{\prime}$ and $\mathrm{M}^{\prime \prime}, \mathrm{N}^{\prime}$ and $\mathrm{N}^{\prime \prime}$, and $\mathrm{H}^{\prime}$ and $\mathrm{H}^{\prime \prime}$ refer to the secondary isozyme bands generated from $\mathrm{M}, \mathrm{N}$, or $\mathrm{H}$, presumably via sequential deamidation (Gracy and Yuan, 1980) ( $\mathrm{M}^{\prime}$ being 1 and $\mathrm{M}^{\prime \prime}$ being 2 deamidations per subunit) or possibly some other posttranslational modification. $\mathrm{H} / \mathrm{N}$ and $\mathrm{M} / \mathrm{N}$ indicate the heterodimer bands composed of undeamidated normal and variant subunits. For simplicity, only the positions of the primary allozymes have been indicated in the schematic for the TPI 1-Manchester phenotype (lane 2) and the TPI 1-Hiroshima-2 phenotype (lane 4). The activity staining pattern following analytical isoelectric focusing is consistent with the pattern observed following polyacrylamide gel electrophoresis (Fig. 3). The isoelectric points (determined at $4^{\circ} \mathrm{C}$ ) of the normai human and rabbit isozymes were 5.9 and 7.4, respectively. The isoelectric points of the Manchester and Hiroshima-2 variant homodimers were 7.4 and 5.2, respectively.

\section{Studies of Subunit Composition}

As seen in Fig. 4 the partially purified isolated TPI allozyme fractions exhibited only a single band of enzyme activity upon reelectrophoresis. A similar purity was observed when fractions containing the Hiroshima-2 variant were reelectrophoresed. The purity of various fractions was further examined by dissociating the isolated enzyme to subunits with $8.0 \mathrm{M}$ urea and then electrophoresing the reassociated enzyme(s). The normal homodimer allozyme fraction $(\mathrm{N} / \mathrm{N})$ yielded only a single band following dissociation and reassociation and thus was presumably composed of a single isozyme with identical subunits (Fig. 5A, well 6). The multiple-banded electrophoretic 


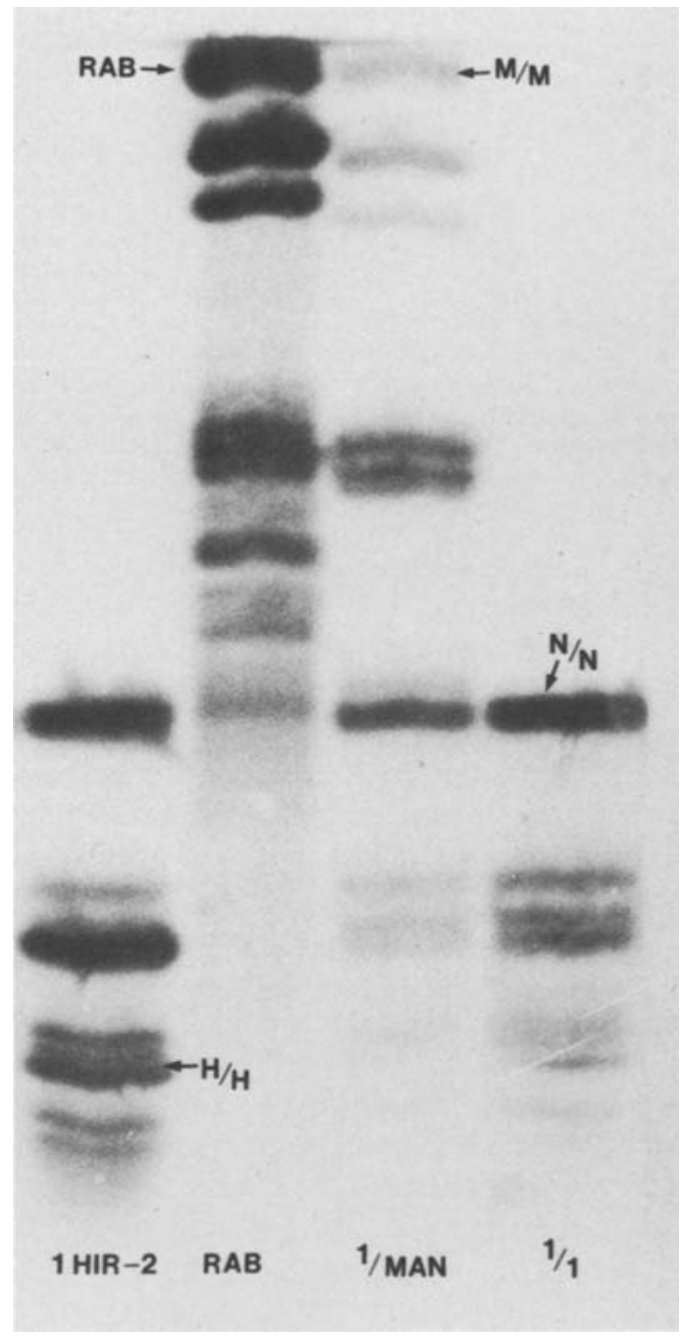

Fig. 3. Isoelectric focusing pattern of TPI variants. The phenotypes are (1) TPI 1-Hiroshima-2, (3) TPI 1Manchester, and (4) TPI 1 . The sample in lane 2 is rabbit muscle TPI. The gels were stained for TPI activity as described in Materials and Methods. The positions of the primary allozymes are designated according to the nomenclature of Fig. 2. 


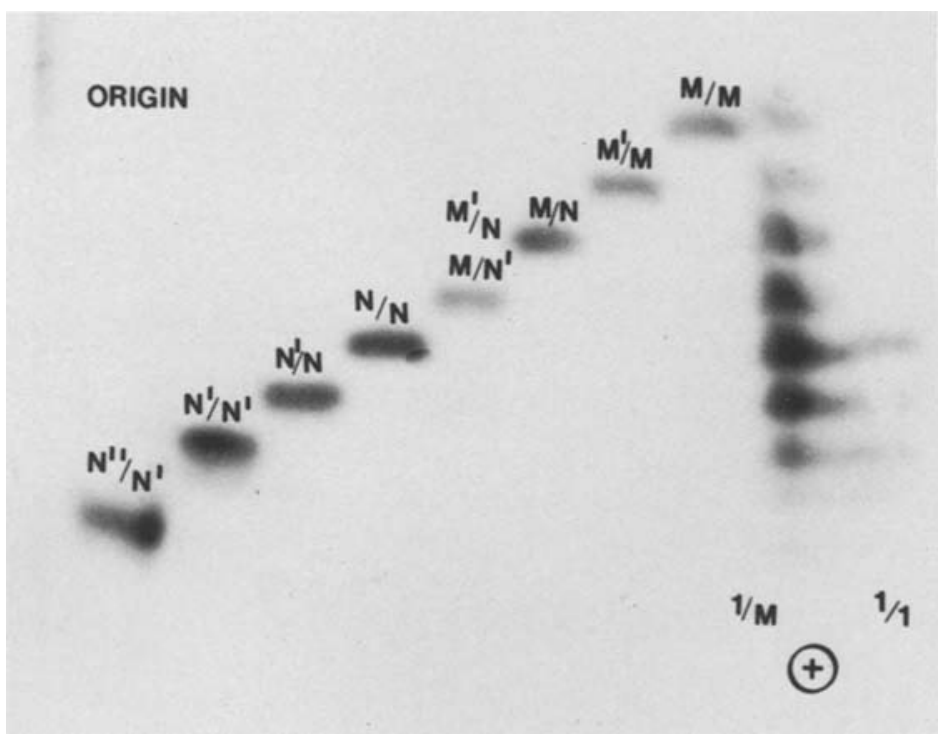

Fig. 4. Polyacrylamide gel electrophoresis of isolated isozyme fractions from TPI 1 and TPI 1-Manchester. The separated isozyme bands were reelectrophoresed after purification. Utilizing the subunit designations from Fig. 2, the samples are $N^{\prime \prime} / N^{\prime}, N^{\prime} / N^{\prime}, N / N^{\prime}, N / N, M / N^{\prime}$, and $M^{\prime} / N, M / N, M / M^{\prime}, M / M$, TPI 1-Manchester, and TPI 1. The gels were stained for TPI activity as described in Materials and Methods.

pattern (Fig. 5A, well 3) of the reassociated Hiroshima-2 variant suggests that the homodimer variant band $(\mathrm{H} / \mathrm{H})$ is contaminated with some deamidated (or otherwise modified) normal subunits. This is not unexpected considering that the electrophoretic mobility of the Hiroshima-2 variant is very similar to that of the second deamidation product of the normal enzyme. Additionally, the banding pattern suggests the deamidated subunits are identical rather than nonidentical.

It has been proposed that specific deamidation steps occur, involving first a site on one TPI subunit (e.g., Asp 15) and then a juxtaposed (e.g., Asp 71) site of the other subunit before the second deamidation occurs on the first subunit (Gracy and Yuan, 1980). This hypothesis was examined by mixing the undeamidated Manchester variant (M/M) and the normal allozyme band corresponding to a loss of two amide groups per $\operatorname{dimer}\left(\mathrm{N}^{\prime} / \mathrm{N}^{\prime}\right.$ or $\left.\mathrm{N}^{\prime \prime} / \mathrm{N}\right)$ prior to urea dissociation-reassociation. The three-banded electrophoretic pattern observed following dissociation and reassociation (Fig. 5B, well 4) is consistent with the hypothesis of sequential steps of deamidation; that is, both subunits of the dimeric molecule must have an identical charge $\left(\mathrm{N}^{\prime} / \mathrm{N}^{\prime}\right)$, each presumably having lost a single amide group. A subunit composition of $\mathrm{N} / \mathrm{N}^{\prime \prime}$ 


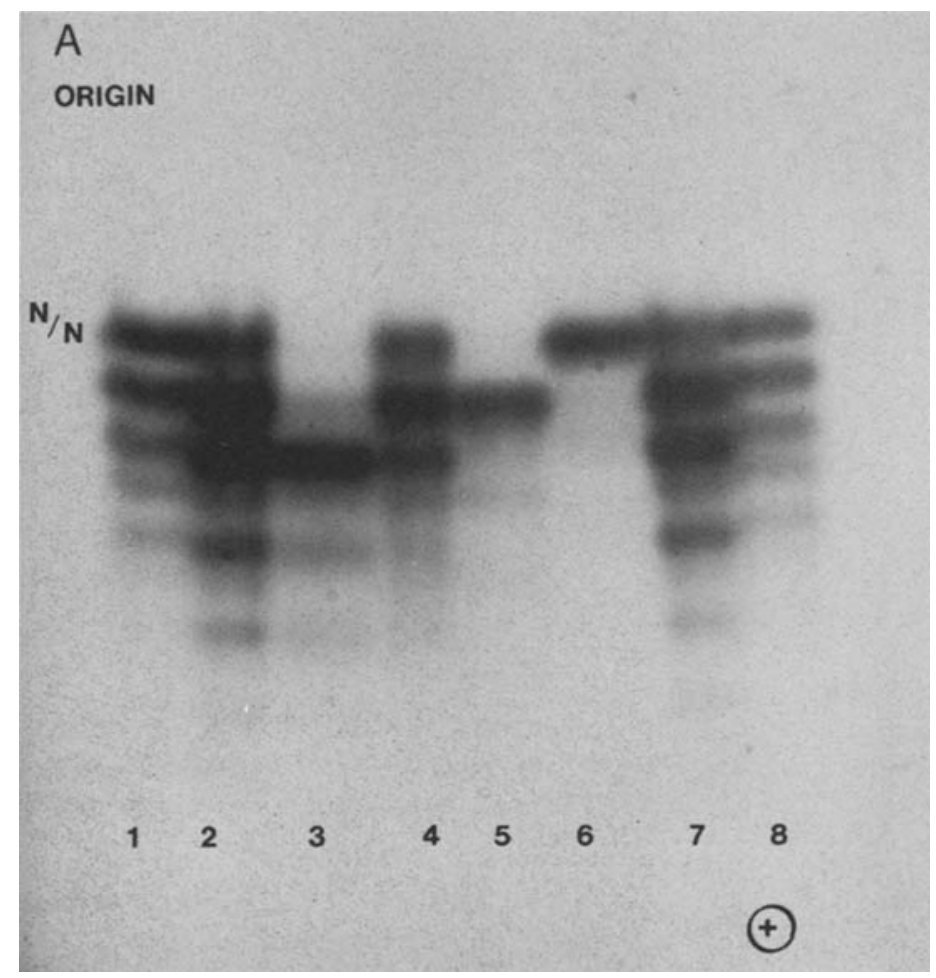

Fig. 5. Electrophoretic analysis of urea dissociated-reassociated TPI. (A) The samples are (1) TPI 1, untreated; (2) TPI 1-Hiroshima-2, untreated; (3) Hiroshima-2 homodimer $(\mathrm{H} / \mathrm{H}$ band), dissociated and reassociated; (4) normal undeamidated $\left(\mathrm{N} / \mathrm{N}^{\prime}\right.$ band $)+$ Hiroshima-2 $(\mathrm{H} / \mathrm{H}$ band), dissociated and reassociated; (5) normal deamidated ( $N / N^{\prime}$ band), untreated; (6) normal homodimer (N/N band), dissociated and reassociated; (7) TPI 1-Hiroshima-2, untreated; and (8) TPI I, untreated. (B) The samples are (1) TPI 1, untreated; (2) TPI 1-Manchester, untreated; (3) Manchester deamidated heterodimer $\left(\mathrm{M} / \mathrm{M}^{\prime}\right.$ band) mixed with normal undeamidated $(\mathrm{N} / \mathrm{N}$ band) before dissociation and reassociation; (4) Manchester undeamidated homodimer (M/M band) mixed with normal twice deamidated $\left(\mathrm{N}^{\prime} / \mathrm{N}^{\prime}\right.$ band) before dissociation and reassociation; (5) Manchester undeamidated ( $M / M$ band) and normal undeamidated homodimers $(\mathrm{N} / \mathrm{N}$ band) mixed before dissociation and reassociation; and (6) TPI 1-Manchester normal heterodimer (M/N band), dissociated and reassociated (the Manchester twice-deamidated molecule would be a contaminant).

would yield a five-banded pattern. A second experiment involved mixing the singly deamidated Manchester variant (1 deamidation/dimer, $M^{\prime} / M$ ) and undeamidated normal allozyme $(\mathrm{N} / \mathrm{N})$. As three types of subunits are involved, a six-banded pattern should be expected except that $\mathbf{M}^{\prime} / \mathbf{M}^{\prime}$ and $M / N$ have the same electrophoretic mobility. This pattern is seen in Fig. 5B, 


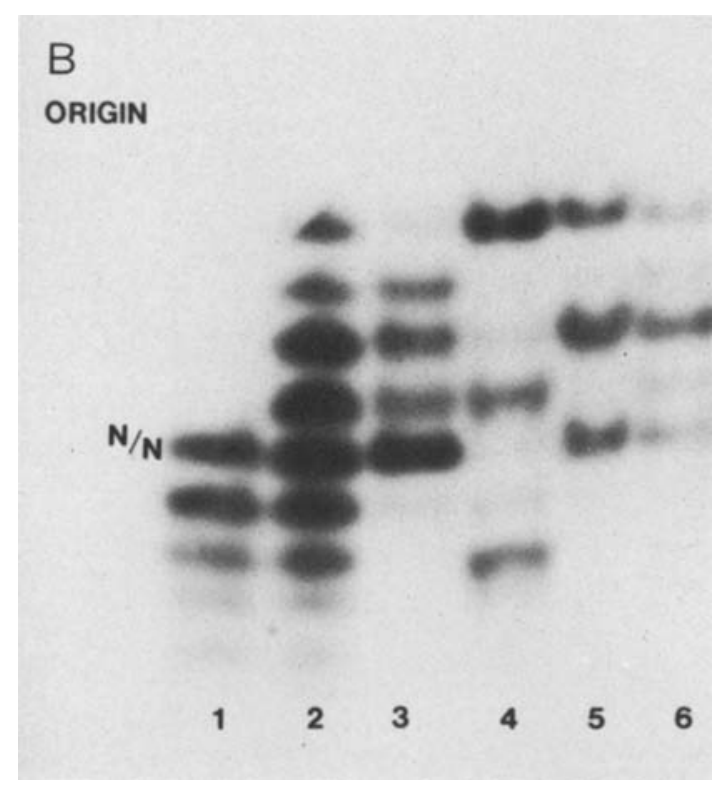

Fig. 5. Continued.

well 3, and confirms that the expected banding pattern will be observed. A similar pattern is observed in Fig. $5 \mathrm{~B}$, well 6 , when the $\mathrm{M} / \mathrm{N}$ heterodimer, which comigrates with the $\mathbf{M}^{\prime} / \mathrm{M}^{\prime}$ homodimer, is dissociated and reassociated; again this pattern is consistent with reassociation of three types of subunits. More important, the position of the bands is consistent with the existence of $\mathbf{M}^{\prime}$ subunits, while there is no indication of $\mathbf{M}^{\prime \prime}$ subunits. Thus, the results of these experiments are consistent with the mechanism proposed by Gracy and Yuan (1980) and indicate that the subunit composition of the allozymes suggested in Fig. 2 is correct.

\section{Stability}

Thermodenaturation studies were conducted at 55 and $57^{\circ} \mathrm{C}$. The Manchester variant is significantly more thermolabile at both temperatures (Fig. 6), retaining approximately $20 \%$ less activity after incubation at $55^{\circ} \mathrm{C}$ for 20 or $30 \mathrm{~min}$ and at $57^{\circ} \mathrm{C}$ for $20 \mathrm{~min}$ than any of the other samples. The $t_{1 / 2}$ at 55 and $57^{\circ} \mathrm{C}$ for the Manchester variant was 16 and $9 \mathrm{~min}$, while it was 26 and $15 \mathrm{~min}$, respectively, for the normal samples. The Manchester variant was also more labile when the studies were conducted with the crude hemolysate fraction or the enzyme preparation following the phosphocellulose fractionation step. In both later experiments, the unseparated allozymes, normal plus 


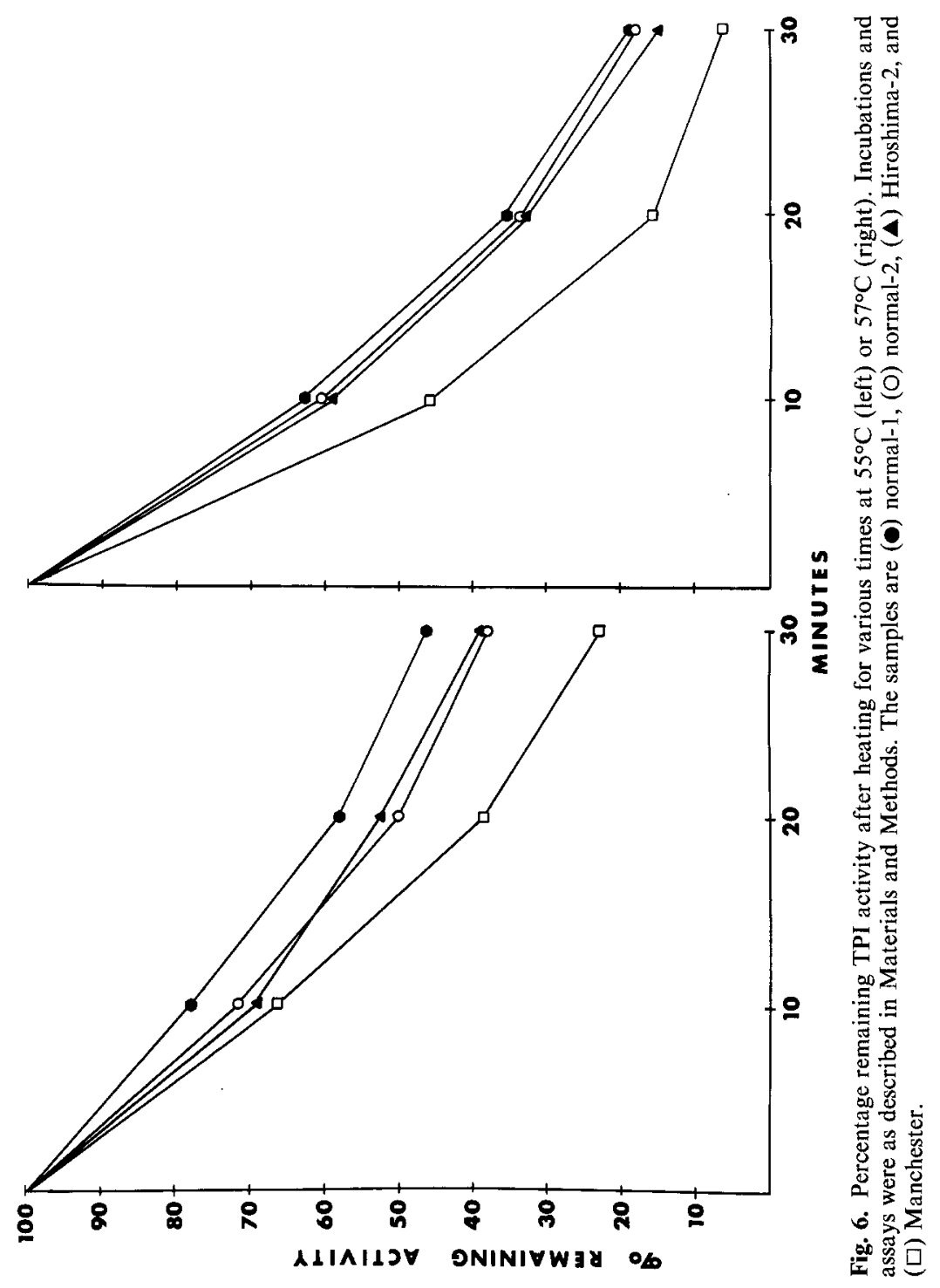


variant, are being studied together, thus, the differences are only 6-8\% rather than the $20 \%$ differences observed with purified allozymes. This smaller difference is as expected, if the lability is a function of the lability of the variant subunit.

No differences among the allozymes in stability to guanidine- $\mathrm{HCl}$ denaturation were evident. All samples retained approximately 70 and $40 \%$ activity after being incubated at $30^{\circ} \mathrm{C}$ for $30 \mathrm{~min}$ in the prescence of 0.9 or 1.1 $\mathrm{M}$ guanidine- $\mathrm{HCl}$.

The stability of the normal allozyme to incubation for $6 \mathrm{hr}$ at $36^{\circ} \mathrm{C}$ at various $p \mathrm{H}$ levels ranging from 2.0 to 11.0 was studied (Fig. 7). The normal allozyme retained approximately $40 \%$ of the initial activity at $p \mathrm{H} 4.5$ and 11.0 , and $90-100 \%$ of the initial activity was retained when the allozyme was incubated at a $p \mathrm{H}$ between 6.0 and 10.0. Both of the variant allozymes had the same $p \mathrm{H}$ stability characteristics as the normal allozymes(s).

\section{Kinetic Studies}

The normal isozyme has a $K_{m}$ for D-glyceraldehyde-3-phosphate of $0.415 \pm$ $0.012 \mathrm{mM}$, while the $K_{m}$ values for the Manchester and Hiroshima-2 variants were 0.403 and $0.415 \mathrm{mM}$, respectively, not significantly different from that of the normal allozyme.

The effects of structurally dissimilar inhibitors of TPI ( $\alpha$-glycerophosphate, inorganic phosphate, 2-phosphoenolpyruvate, and frustose-1,6-diphosphate) were studied, in each case with D-glyceraldehyde-3-phosphate $(0.42$ $\mathrm{mM}$ ) as substrate. The inhibitor concentrations were selected in order to inhibit approximately 30 and $70 \%$ of the activity of the normal allozyme,

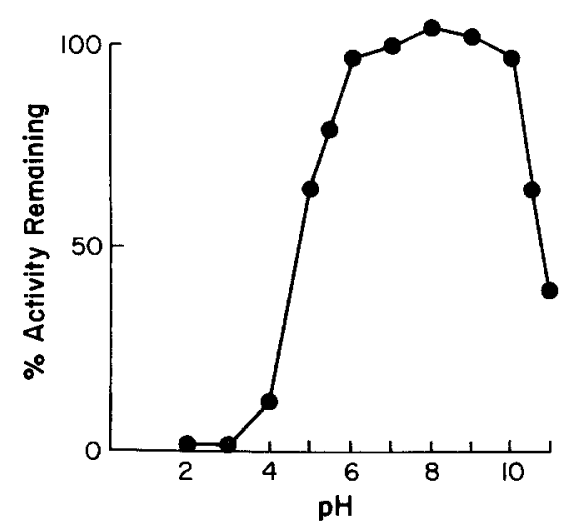

Fig. 7. Percentage remaining TPI activity after incubation of the normal allozyme at various $p \mathrm{H}$ levels for $6 \mathrm{hr}$. 
respectively (Burton and Waley, 1968). Neither of the variants was more or less sensitive to inhibition than was the normal allozyme fraction (Table II). Preincubation of the enzyme with the inhibitor changed the extent of inhibition, but again no allozyme specificity was observed.

\section{Immunological Studies}

Immunoinactivation studies to detect differences in sequence and/or conformation were conducted using antisera produced in roosters against normal human TPI. As seen in Fig. 8, the Hiroshima-2 variant is less inhibited by equivalent quantities of antisera than were the other two allozymes. The Hiroshima-2 variant is associated with normal levels of enzyme activity in the original hemolysate and has normal kinetic parameters, and the specific activity at each of the steps during purification was similar to that of both the normal and the Manchester enzyme; thus, it is suggested that the difference in inactivation between the Hiroshima-2 variant and the other allozymes reflects differences in the avidity of the antibody-enzyme complex, although the possibility that the Hiroshima-2 variant has a lower specific activity cannot be conclusively excluded.

\section{DISCUSSION}

Extensive studies of the structure and kinetic properties of TPI from a wide variety of sources have been published. Insights into the important structural constraints on the catalytic mechanism have come from sequence compari-

Table II. Effect of Various Inhibitors on the Activity of Normal TPI Isolated from Human Erythrocytes $^{a}$

\begin{tabular}{cc}
\hline Inhibitor & \% remaining activity \\
\hline$\alpha$-Glycerophosphate & \\
$1.12 \mathrm{mM}$ & $67 \pm 0.5$ \\
$4.93 \mathrm{mM}$ & $26 \pm 0.4$ \\
Inorganic phosphate & $80 \pm 1.0$ \\
$1.73 \mathrm{mM}$ & $57 \pm 1.2$ \\
$5.21 \mathrm{mM}$ & \\
2-Phosphoenolypyruvate & $82 \pm 0.6$ \\
$0.09 \mathrm{mM}$ & $45 \pm 1.2$ \\
$0.45 \mathrm{mM}$ & $72 \pm 1.5$ \\
Fructose-1,6-diphosphate & $35 \pm 0.4$ \\
$7 \mathrm{mM}$ & \\
$35 \mathrm{mM}$ & \\
\hline
\end{tabular}

${ }^{a}$ Assays were conducted as described in Materials and Methods except that the D-glyceraldehyde-3-phosphate concentration was $0.42 \mathrm{mM}$. The inhibitor concentration refers to the final concentration present in the assay. $100 \%$ activity was the level of activity determined in the absence of added inhibitor. 


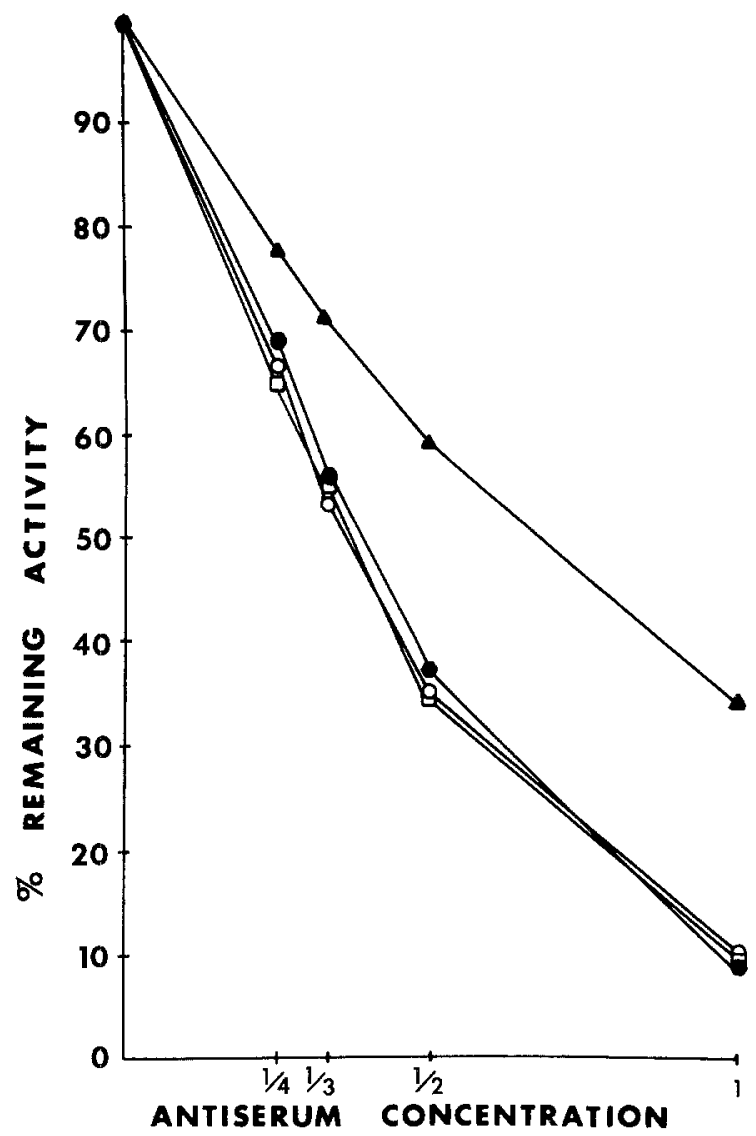

Fig. 8. Percentage remaining TPI activity after incubation of the partially purified allozyme with human TPI antiserum. Incubation and assays were as described in Materials and Methods. The samples are (•) normal-1, (O) normal-2, (A) Hiroshima-2, and ( $\square$ ) Manchester.

sons of the enzyme from different sources (Banner et al., 1975), while only limited characterization of genetic variants has been reported (Peters et al., 1973).

The two variants described here, TPI-Manchester and TPI-Hiroshima2 , are unique electrophoretic variants associated with normal levels of enzyme activity in the hemolysates of the affected individuals. Each variant has a $K_{m}$ for D-glyceraldehyde-3-phosphate which is similar to the $K_{m}$ obtained for electrophoretically normal enzyme. Also, the sensitivity to inhibition by four different inhibitors was similar to that observed for the normal enzyme. It seems unlikely that either amino acid substitution significantly alters the conformation of the active site. 
The unique characteristic of the Manchester variant, in addition to an electrophoretic mobility consistent with a net charge change of +2 units per subunit, is the thermolability of the enzyme. This conformational alteration associated with increased thermolability is not reflected in an increased sensitivity to guanidine hydrochloride denaturation or inactivation by incubation at either acid or basic $p \mathrm{H}$. The thermolability does not appear to be associated with in vivo lability in that the affected individuals have normal levels of enzyme activity.

The unique antigenic character of the Hiroshima-2 variant indicates that this amino acid substitution or deletion either may be on the surface of the molecule or causes a conformational change in the region of the antibody binding site(s). As with the Manchester variant, this structural change does not affect the active site region of the enzyme, at least to the extent that it does not alter the kinetic properties of the molecule.

Labile asparagine residues have been identified at positions 15 and 71 of the rabbit isozyme (Corran and Waley, 1974) and crystallographic data suggest that residue 15 of one subunit is located proximal to residue 71 of the other subunit (Banner et al., 1975). It has also been reported by Gracy and Yuan (1980) that the loss of one amide group increases the lability of the juxtaposed amide group in the human isozyme. Dissociation-reassociation experiments involving various combinations of normal and variant subunits are consistent with this sequential deamidation hypothesis. The sequence of the enzyme from the human has recently been determined and found to be very similar to that observed in other species (Yuan et al., 1981). Accordingly, it should be possible to relate the characteristics of genetic variants to specific structural alterations. Identification of the change in primary sequence of the variant enzymes should provide additional data regarding the apparently severe conformation constraints on the catalytic and subunit interactions sites of an enzyme and which could be associated with its slow rate of evolution. It is possible that these constraints are also related to the existence of null alleles at an unexpectedly high frequency.

\section{ACKNOWLEDGMENTS}

We are grateful to Dr. K. Goriki for collecting blood samples of the Hiroshima variant and Dr. H. Gershowitz for assistance with the immunological studies. The advice and assistance of Mr. S. Decker are also gratefully acknowledged.

\section{REFERENCES}

Banner, D. W., Bloomer, A. C., Petsko, G. A., Phillips, D. C., Pogson, C. I., Wilson, I. A., Corran, P. H., Furth, A. J., Milman, J. D., Offord, R. E., Priddle, J. D., and Waley, S. G. (1975). Structure of chicken muscle triose phosphate isomerase determined crystallographically at $2.5 \AA$ A resolution using amino acid sequence data. Nature (Lond.) 255:609. 
Bergmeyer, H. U. (1974). In Bergmeyer, H. U. (ed.), Methods of Enzymatic Analysis, Academic Press, New York, p. 1314.

Burton, P. M., and Waley, S. G. (1968). Kinetics of triose phosphate isomerase. Biochem. Biophys. Acta 151:714.

Corran, P. H., and Waley, S. G. (1974). The tryptic peptides of rabbit muscle triose phosphate isomerase. Biochem. $J$. 139:1.

Dayhoff, M. O. (1978). Survey of new data and computer methods of analysis. In Dayhoff, M. O. (ed.), Atlas of Protein Sequence and Structure, Vol. 5, National Biomedical Research Foundation, Silver Spring, Md., p. 3.

Decker, R. S., and Mohrenweiser, H. W. (1981). Origin of the triosephosphate isomerase isozymes in humans: Genetic evidence for the expression of a single structural locus. $\mathrm{Am} . J$. Hum. Genet. 33:683.

Eber, S. W., and Krietsch, W. K. G. (1980). The isolation and characterization of the multiple forms of human skeletal muscle triosephosphate isomerase. Biochim. Biophys. Acta 614:173.

Eber, S. W., Dunnwald, M., Belohradsky, B. H., Bidlingmaier, F., Schievelbein, H., Weinmann, H. M., and Krietsch, W. K. G. (1979). Hereditary deficiency of triosephosphate isomerase in four unrelated families. Eur. J. Clin. Invest. 9:195.

Eber, S. W., Belohradsky, B. H., and Krietsch, W. K. G. (1981). A case for triosephosphate isomerase testing in congenital non-spherocytic hemolytic anemia. J. Pediat. (in press).

Fielek, S., and Mohrenweiser, H. W. (1979). Erythrocyte enzyme deficiencies assessed with a miniature centrifugal analyzer. Clin. Chem. 25:384.

Gracy, R. W. (1974). Nature of the multiple forms of glucosephosphate and triosephosphate isomerase. In Markert, C. L. (ed.), Isozymes. I. Molecular Structure, Academic Press, New York, p. 471.

Gracy, R. W. (1975). Triosephosphate isomerase from human erythrocytes. Methods Enzymol 41:442.

Gracy, R. W., and Yuan, P. M. (1980). Spontaneous deamidation of two asparagines within the subunit contact sites of human triosephosphate isomerase. Fed. Proc. 39:1960.

Hartman, F. C., and Gracy, R. W. (1973). An active-site peptide from human triose phosphate isomerase. Biochem. Biophys. Res. Comm. 52:388.

Krietsch, W. K. G., Pentchev, P. G., Klingenbürg, H., Hofstätter, T., and Bücher, T. (1970). The isolation and crystallization of yeast and rabbit liver triose phosphate isomerase and a comparative characterization with the rabbit muscle enzyme. Eur. J. Biochem. 14:289.

Maurer, H. R., and Allen, R. C. (1972). Useful buffer and gel systems for polyacrylamide gel electrophoresis. Z. Klin. Chem. Klin. Biochem. 10:220.

Mohrenweiser, H. W. (1981). Frequency of enzyme deficiency variants in erythrocytes of newborn infants. Proc. Natl. Acad. Sci. USA 78:5046.

Neel, J. V. (1978). Rare variants, private polymorphisms, and locus heterozygosity in Amerindian populations. Am. J. Hum. Genet. 30:465.

Neel, J. V., Mohrenweiser, H. W., and Meisler, M. M. (1980a). Rate of spontaneous mutation at human loci encoding protein structure. Proc. Natl. Acad. Sci. USA 77:6037.

Neel, J. V., Satoh, C., Hamilton, H. B., Otake, M., Goriki, K., Kogoeka, T., Fujita, M., Neriishi, S., and Asakawa, J. (1980b). Search for mutations affecting protein structure in children of atomic bomb survivors; Preliminary report. Proc. Natl. Acad. Sci. USA 77:4221.

Ogita, Z., and Markert, C. L. (1979). A miniaturized system for electrophoresis on polyacrylamide gels. Anal. Biochem. 99:233.

Peters, J., Hopkinson, D. A., and Harris, H. (1973). Genetic and non-genetic variation of triose phosphate isomerase isozymes in human tissues. Ann. Hum. Genet. Lond. 36:297.

Porter, D. W., Harris, B. G., and Gracy, R. W. (1973). Removal of triosephosphate isomerase from albumins. Prep. Biochem. 3:149.

Putman, S. J., Coulson, A. F. W., Farley, I. R. T., Riddleston, B., and Knowles, J. R. (1972). Specificity and kinetics of triosephosphate isomerase from chicken muscle. Biochem. $J$. 129:301.

Rozacky, E. E., Sawyer, T. H., Barton, R. A., and Gracy, R. W. (1971). Studies on human triosephosphate isomerase I. Isolation and properties of the enzyme from erythrocytes. Arch. Biochem. Biophys. 146:312. 
Rubinson, H., Meienhofer, M. C. and Dreyfus, J. C. (1973). A new isozyme of triosephosphate isomerase specific to Hominoids. J. Mol. Evol. 2:243.

Satoh, C., and Mohrenweiser, H. W. (1979). Genetic heterogeneity within an electrophoretic phenotype of phosphoglucose isomerase in a Japanese population. Ann. Hum. Genet. Lond. 43:283.

Sawyer, T. H., Tilley, B. E., and Gracy, R. W. (1972). Studies on human triosephosphate isomerase. II. Nature of the electrophoretic multiplicity in erythrocytes. J. Biol. Chem. 247:6499.

Schneider, A. S., Valentine, W. N., Hattori, M., and Heins, H. L. (1965). Hereditary hemolytic anemia with triosephosphate isomerase deficiency. New Engl. J. Med. 272:229.

Schneider, A. S., Dunn, I., Ibsen, K. H., and Weinstein, I. W. (1968). Triosephosphate isomerase deficiency. Inherited triosephosphate deficiency. Erythrocyte carbohydrate metabolism and preliminary studies of the erythrocyte enzyme. In Beutler, E. (ed.), Hereditary Disorders of Erythrocyte Metabolism, City of Hope Symposium Series, Vol. 1, Grune and Stratton, New York, p. 273.

Scopes, R. K. (1968). Methods for starch gel electrophoresis of sarcoplasmic proteins. Biochem. J. 107:139.

Skala, H., Dreyfus, J. C., Vives-Corrons, J. L., Matsumoto, F., and Beutler, E. (1977). Triosephosphate isomerase deficiency. Biochem. Med. 18:226.

Snapka, R. M., Sawyer, T. H., Barton, R. A., and Gracy, R. W. (1974). Comparison of the electrophoretic properties of triosephosphate isomerase of various tissues and species. Comp. Biochem. Biophys. 49B:733.

Tiffany, T. O., Chilcote, D. D., and Burtis, C. A. (1973). Evaluation of kinetic enzyme parameters by use of a small computer interfaced 'Fast Analyzer'-an addition to automated clinical enzymology. Clin. Chem. 19:908.

Wilkinson, G. N. (1961). Statistical estimations in enzyme kinetics. Biochem. J. 80:324.

Vives-Corrons, J. L., Robinson-Skala, H., Mateo, M., Estella, J., Feliu, E., and Dreyfus, J. C. (1978). Triosephosphate isomerase deficiency with hemolytic anemia and severe neuromuscular disease. Familial and biochemical studies of a case found in Spain. Hum. Genet. 42:171.

Yuan, P. M., Dewan, R. N., Zaun, M., Thompson, R. E., and Gracy, R. W. (1979). Isolation and characterization of triosephosphate isomerase isozymes from human placenta. Arch. Biochem. Biophys. 198:42.

Yuan, P. M., Talent, J. M., and Gracy, R. W. (1981). Elucidation of the sequence of human triosephosphate isomerase by homology peptide mapping. Biochim. Biophys. Acta 671:211. 